
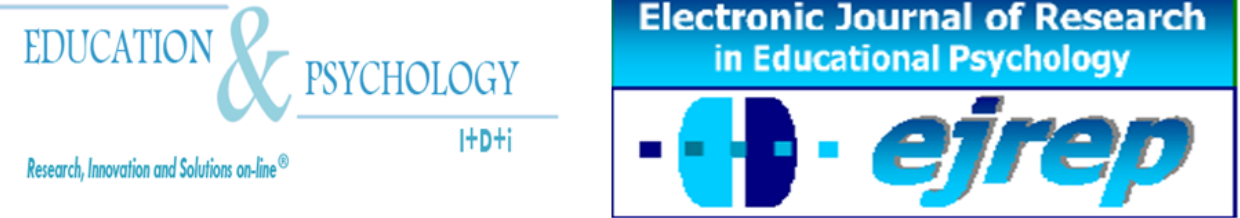

Editorial EOS

\title{
Predicting Academic Success and Psychological Wellness in a Sample of Canadian Undergraduate Students
}

Henry P.H. Chow

Department of Sociology \& Social Studies, University of Regina, Saskatchewan

\section{Canada}

Correspondence: Henry P.H. Chow. Department of Sociology \& Social Studies, University of Regina. 3737 Wascana Parkway. Regina, SK, S4S 0A2 Canada. E-mail: henry.chow@uregina.ca

(C) Education \& Psychology I+D+i and Editorial EOS (Spain) 


\begin{abstract}
Introduction. University students need to cope with a complex new life role and to achieve academic success. This article explores the academic performance and psychological wellbeing among university students in a western Canadian city.

Method. Using a convenience sample, a total of 501 undergraduate students in Regina, Saskatchewan took part in a self-administered questionnaire survey.

Results. Multiple ordinary least-squares regression analyses demonstrated that older students and those who were more satisfied with their physical health, reported a higher level of psychological well-being, indicated higher educational aspirations, attended classes on a more regular basis, spent more time on studying, and those whose fathers had a higher level of educational attainment were found to perform better academically. On the other hand, male respondents and those who were more satisfied with their physical appearance, self-image, or relationship with their significant other, scored higher on life satisfaction scale, reported a stronger sense of life purpose were found to report a higher level of psychological well-being.
\end{abstract}

Discussion or Conclusion. The results of this study contribute to the research literature on students' well-being and performance. Through increased understanding of the determinants of both outcome variables, educators, counsellors, academic advisors, and community health professionals will be better equipped to design intervention strategies which improve students' learning outcomes and enhance their quality of life.

Keywords: University students, academic performance, psychological well-being, higher education

Received: 12/15/09 Initial Acceptance: 03/10/10 Definitive Acceptance: 07/08/10 


\section{Predicción de éxito académico y bienestar psicológico en una muestra de estudiantes universitarios canadienses}

\section{Resumen}

Introducción. Los estudiantes universitarios necesitan enfrentarse con nuevos y complejos roles y conseguir el éxito académico. Este artículo explora la ejecución académica y el bienestar psicológico entre estudantes universitarios de Canadá.

Método. Utilizando una muestra de conveniencia, un total de 501 estudiantes de Regina, Saskatchewan participaron en el estudio mediante un autoinforme.

Resultados. Los análisis de regresión multiple mostraron que los alumnos mayores y los más satisfechos con su salud física tenían mayores niveles de bienestar psicológico, indicaron mayores aspiraciones educativas, iban a clase con más regularidad, pasaban más tiempo estudiando, y aquellos cuyos padres tenían un nivel educativo mayor obtuvieron mejores resultados académicos. Por otro lado, los hombres más satisfechos con su apariencia física, su autoimagen, o con sus relaciones con los demás, puntuaron más alto en la escala de satisfacción vital, informaron de un mayor sentido de aspiraciones vitales y obtuvieron mayores niveles de bienestar psicológico.

Discusión y Conclusiones. Los resultados del estudio contribuyen a la investigación en bienestar y ejecución académica de los estudiantes. Aumentando la comprensión de los factores que influyen en ambas variables los educadores, orientadores, consejeros académicos y profesionales de la salud estarán más equipados para diseñar estrategias de intervención que permitan mejorar los resultados del aprendizaje y conectarlos con la calidad de vida.

Palabras clave: universitarios, ejecución académica, bienestar psicológico, educación superior

Recibido: 15/12/09 Aceptación Inicial: 10/03/10 Aceptación Definitiva: 08/07/10 


\section{Introduction}

A nation's investments in human capital are as vital as their stock of physical capital and their natural resource endowments. College and university education provides individuals with the knowledge and tools they need to understand and participate in today's highly competitive world. Canadians place a high value on higher education. A recent survey of Canadian attitudes on post-secondary education commissioned by the Canadian Council on Learning showed that an overwhelming majority of Canadians believe that the pace of the change in the world makes it more important than ever to ensure that people can get more education or training at any time of their life (Pacific Issues Partners, 2006). In fact, Canada surpassed 23 of the 30 member nations of the Organization for Economic Co-operation and Development in 2007 concerning the proportion of its population aged 25 to 64 that held a university degree (Statistics Canada, 2009a).

The preference of the labour market for skilled workers to compete in a global and technologically advanced economy, the immigration policies aimed at attracting highly skilled immigrants, and the recession of the early 1990s that was particularly difficult for Canadian youth are the three key factors identified by Statistics Canada (2003a) that contributed to the remarkable growth in the number of Canadians with a post-secondary education in the 1990s. The 2001 Canadian census revealed that $28 \%$ of all individuals aged 25 to 34 possessed university qualifications, and $21 \%$ held a college diploma (Statistics Canada, 2003b). During the academic year 2008-2009, Canadian universities enrolled a total of 1,112,300 fulltime and part-time undergraduate students. ${ }^{1}$ Three fields of study accounted for one-half of total enrolment, including (1) social and behavioral sciences, and law; (2) business, management and public administration; and (3) the humanities (Statistics Canada, 2010).

Doubtlessly, the pursuit of a higher education entails both an investment of a substantial amount of financial resources ${ }^{2}$ and a strong commitment of time and effort. University life adds more stress and requires more independent decision making by young people. Students' academic achievement as an important educational outcome (Bean \& Bradley, 1986; Kaufman \& Creamer, 1991; Pike, 1991; Terenzini, Pascarela, \& Lorang, 1982) and their psychological well-being as a key determinant of health status, therefore, warrant serious research attention. 
There is a growing body of research literature on students' academic performance. Previous studies involving post-secondary students have demonstrated that some of the key determinants include gender (Baker, 2004; Clifton, 1997; Keller, Crouse, \& Trusheim, 1993; Mau \& Lynn, 2001), socio-economic status (Hansen \& Mastekaasa, 2006; Ross, Cleland, \& MacLeod, 2006), employment status (Applegate \& Daly, 2006; Hunt, Lincoln, \& Walker, 2004), high school grades (DeBerard, Spielmans, \& Julka, 2004; Duff, 2004; Hall, Smith, \& Chia, 2008; Mattson, 2007; Olani, 2009; Zwick \& Sklar, 2005), high school environment (Pike \& Saupe, 2002; Wolniak \& Engberg, 2010), personality traits (Musgrave-Marquart, Bromley, \& Dalley, 1997; Nguyen, Allen, \& Fraccastoro, 2005; Ridgell \& Lounsbury, 2004; Tross, Harper, Osher, \& Kneidinger, 2000), health status (Mattison, 2006; Trockel, Barnes, \& Egget, 2000), satisfaction with academic life (Chambel \& Curral, 2005; Graunke \& Woosley, 2005), amount of time devoted to study (Jackson, Weiss, Lundquist, \& Hooper, 2003; Nonis \& Hudson, 2006), styles of learning (Diseth, 2002; Wilding \& Andrews, 2006), achievement motivation (Morris, Brooke, \& May, 2003; Roebken, 2007; Steinberg, 2006), and social support (Clifton, Perry, Roberts, \& Peter, 2008; Cutrona, Cole, Colangelo, Assouline, \& Russell, 1994; Orpen, 1996; Spitzer, 2000; Walker \& Satterwhite, 2002).

Concerning psychological well-being, gender (Cook, Bewick, Barkham, Bradley, \& Austin, 2006), socio-economic status (Tong \& Song, 2004), family cohesion (DysonWashington, 2006; Frey, Beesley, \& Miller, 2006; Heris \& Revilla, 1994; Kazarian, 2005; Love \& Murdock, 2004), personality traits (Chang, 2006; Nguyen et al., 2005), academic workload (Monk \& Mahmood, 1999), achievement motivation (Elliot, Sheldon, \& Church, 1997; Tomiki, 2000), physical exercise (Lee \& Yuen-Loke, 2005; Maltby \& Day, 2001; Markland \& Ingledew, 1997), social support (Edwards Hershberger, Russell, \& Markert, 2001; Gencoz \& Ozlale, 2004; Morris, 1997; Rodriguez, Mira, Myers, Morris, \& Cardoza, 2004; Solberg \& Villarreal, 1997), and social problem solving orientation (McCabe, Blankstein, \& Mills, 1999; Miller, 2001) have been identified as significant predictors of students' psychological well-being. Various comparative studies have also provided evidence that post-secondary students fared worse than the general population on measures of psychological well-being (Roberts, Golding, Towell, \& Weinreb, 1999; Stewart-Brown et al., 2000). As university students face a myriad of challenges and stressors in the academic environment and relatively little research attention has been given to those who study in smaller Canadian 
cities, this article attempts to explore the determinants of the academic achievement and psychological well-being among undergraduate students in Regina, Saskatchewan.

\section{Method}

\section{Participants}

This analysis is based on data collected as part of a larger investigation into the social attitudes and general well-being among university students in Regina during the academic year 2003-04 (Chow, 2008). Using a convenience sample, a total of 501 undergraduate students at the University of Regina took part in a self-administered questionnaire survey. The sample consisted of 147 (29.7\%) male and 348 (70.3\%) female students ${ }^{3}$ with a mean age of 21.42 years $(S D=4.91)$. Caucasian students $(n=443,89.9 \%)$ and Canadian citizens $(n=484$, $98.0 \%$ ) constituted an overwhelming majority of the sample. A sizable proportion of the respondents were registered with the Faculties of Arts $(n=276,55.4 \%)$, Administration $(n=49$, $9.8 \%)$, Science $(n=49,9.8 \%)$, Social Work $(n=38,7.6 \%)$, Kinesiology $(n=21,4.2 \%)$, and Education ( $n=21,4.2 \%)$. Regarding marital status, most were never married or single $(n=$ 426, 86.1\%). A significant proportion of the respondents indicated either Protestantism $(n=$ $138,30.1 \%)$ or Catholicism $(n=173,37.8 \%)$ as their religious affiliation. Over half of the sample had a father $(n=251,53.0 \%)$ or a mother $(n=273,56.6 \%)$ with post-secondary education. As well, over half of the sample $(n=257,56.7 \%)$ reported an annual family income of more than $\$ 60,000$.

\section{Instrument}

A 10-page questionnaire containing 30 questions was administered to all participants. The self-administered survey instrument consisted of questions developed by the researcher to measure students' academic performance and well-being. Demographic information, including sex, age, marital status, religious affiliation, employment status, race/ethnic background, socio-economic status, and parents' educational attainment, was also collected. 
Procedure

With the co-operation of the faculty members in the Department of Sociology and Social Studies, self-administered questionnaires were distributed to various Sociology and Social Studies classes. Students were informed both in writing and verbally that participation was voluntary and that return of their completed survey would serve as their participation consent. The survey took approximately 20 minutes to complete and no incentive was provided. Although the respondents were recruited from Sociology and Social Studies classes, it should be emphasized that these 501 students were officially registered with quite a number of faculties and schools, including Administration, Arts, Education, Engineering, Fine Arts, Journalism, Kinesiology, Science, and Social Work.

\section{Statistical Analysis}

Descriptive and inferential analyses were conducted using the Statistical Package for the Social Sciences. The internal consistency of all scales used was assessed by Cronbach's alpha reliability test. Two multiple ordinary least-squares regression models were constructed to identify the major determinants of respondents' academic performance and psychological well-being.

\section{Results}

Measures of Academic Performance and Psychological Well-being

Academic Performance. Self-reported grade point average (GPA) was used to measure students' academic performance. Nearly half of the respondents $(n=227,46.8 \%)$ obtained an average of $70-79 \%$. About a quarter of the sample received a GPA of $60-69 \%(n=123$, $25.4 \%)$ or $80-89 \%(n=113,23.3 \%)$. Relatively few students reported a passing GPA of 50$59 \%(n=18,3.7 \%)$ or a GPA of $90 \%$ or higher $(n=4, .8 \%)$.

Psychological Well-being. The frequency of feeling sad, lonely, stressed, like crying, depressed, and hopeless in the past 30 days was used to measure students' psychological well-being. The response categories ranged from 1 to 5 , with $1=$ never, $2=$ very infrequently, $3=$ infre- 
quently, $4=$ frequently, and $5=$ very frequently. As displayed in Table $1,75.1 \%(n=374)$ felt stressed, $28.3 \%(n=140)$ felt like crying, $25.5 \%(n=126)$ felt sad, $24.7 \%(n=122)$ felt lonely, 19.3\% $(n=95)$ felt depressed, and 9.5\% $(n=47)$ felt hopeless. An additive scale was constructed $(M=19.46, S D=4.92)$ and was found to be internally consistent, with a Cronbach's alpha reliability coefficient of .85 .

Table 1. Descriptive statistics for items measuring psychological well-being

\begin{tabular}{lccccccc}
\hline & 1 & 2 & 3 & 4 & 5 & & \\
& $\mathrm{~N}$ & $\mathrm{~N}$ & $\mathrm{~N}$ & $\mathrm{~N}$ & $\mathrm{~N}$ & $\mathrm{M}$ & $\mathrm{SD}$ \\
& $(\%)$ & $(\%)$ & $(\%)$ & $(\%)$ & $(\%)$ & & \\
\hline a. Sad & 29 & 136 & 204 & 101 & 25 & 2.91 & .954 \\
b. Lonely & $(5.9)$ & $(27.5)$ & $(41.2)$ & $(20.4)$ & $(5.1)$ & & \\
& 81 & 135 & 157 & 93 & 29 & 2.71 & 1.125 \\
c. Stressed & $(16.4)$ & $(27.3)$ & $(31.7)$ & $(18.8)$ & $(5.9)$ & & \\
& $(1.4)$ & 39 & 78 & 220 & 154 & 3.95 & .951 \\
d. Like crying & 105 & 113 & 138 & 106 & 34 & 2.70 & 1.215 \\
& $(21.2)$ & $(22.8)$ & $(27.8)$ & $(21.4)$ & $(6.9)$ & & \\
e. Depressed & 130 & 147 & 120 & 72 & 23 & 2.41 & 1.160 \\
& $(26.4)$ & $(29.9)$ & $(24.4)$ & $(14.6)$ & $(4.7)$ & & \\
f. Hopeless & 255 & 122 & 71 & 36 & 11 & 1.84 & 1.061 \\
& $(51.5)$ & $(24.6)$ & $(14.3)$ & $(7.3)$ & $(2.2)$ & & \\
& & & & &
\end{tabular}

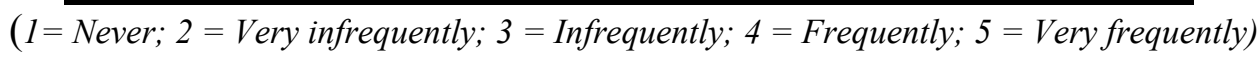

\section{Major Factors Affecting Academic Performance and Psychological Well-being}

To disentangle the factors affecting university students' academic performance and psychological well-being, two models using multiple ordinary-least squares (OLS) regression analysis were constructed.

Academic Performance. Eleven predictor variables, ${ }^{4}$ including sex, age, religion, employment status, physical health, psychological well-being, educational aspirations, class attendance, hours spent on studying, father's education, and socio-economic status, were included in the OLS regression model for academic performance. The overall OLS regression model, as presented in Table 2, was found to be significant $\left(F_{(11,489)}=8.73, p<.001\right)$ and accounted for 
$14.5 \%$ of the variation in academic performance. Age $(\beta=.108, p<.05)$, physical health $(\beta=.099, p<.05)$, psychological well-being $(\beta=.102, p<.05)$, educational aspirations $(\beta=.183$, $p<.001)$, class attendance $(\beta=.108, p<.05)$, hours spent on studying $(\beta=.193, p<.001)$, and father's education $(\beta=.121, p<.01)$ were found to be significantly associated with academic performance. More specifically, older students and those who were more satisfied with their physical health, reported a higher level of psychological well-being, indicated a higher educational aspirations, attended classes on a more regular basis, spent more time on studying, and whose fathers had a higher level of educational attainment were found to have obtained a higher GPA.

Table 2. Unstandardized and standardized regression coefficients for effects of sociodemographic and background variables on academic performance

\begin{tabular}{|c|c|c|}
\hline & $\mathrm{b}$ & $\beta$ \\
\hline 1. Sex & -.086 & -.0489 \\
\hline 2. Age & .018 & $.108 *$ \\
\hline 3. Religion & -.069 & -.042 \\
\hline 4. Employment status & -.005 & -.003 \\
\hline 5. Physical health & .087 & $.099 *$ \\
\hline 6. Psychological well-being & .017 & $.102 *$ \\
\hline 7. Educational aspirations & .181 & $.183 * * *$ \\
\hline 8. Class attendance & .112 & $.108 *$ \\
\hline 9. Hours spent on studying & .014 & $.193 * * *$ \\
\hline 10. Father's education & .077 & $.121 * *$ \\
\hline 11. Socio-economic status & .031 & .075 \\
\hline (Constant) & \multicolumn{2}{|c|}{1.109} \\
\hline $\mathrm{F}$ & \multicolumn{2}{|c|}{$8.730 * * *$} \\
\hline $\mathrm{R}^{2}$ & \multicolumn{2}{|c|}{.164} \\
\hline Adjusted $\mathrm{R}^{2}$ & \multicolumn{2}{|c|}{.145} \\
\hline $\mathrm{N}$ & \multicolumn{2}{|c|}{501} \\
\hline
\end{tabular}

Psychological Well-being. Thirteen predictor variables, ${ }^{5}$ including sex, employment status, socio-economic status, religious involvement, physical health, physical appearance, self- 
image, life satisfaction, life purpose, relationship with significant other, relationship with family, relationship with friends, and academic performance, were included in the OLS regression model for psychological well-being. The overall regression model, as shown in Table 3, was found to be significant $\left(F_{(13,487)}=16.038, p<.001\right)$ and explained $28.1 \%$ of the variation in psychological well-being. Sex $(\beta=.24, p<.001)$, physical appearance $(\beta=.143, p<.01)$, selfimage $(\beta=.113, p<.05)$, life satisfaction $(\beta=.234, p<.001)$, life purpose $(\beta=.094, p<.05)$, and relationship with significant other $(\beta=.085, p<.05)$ were found to be significantly related to psychological well-being. Put succinctly, male respondents and those who were more satisfied with their physical appearance, self-image, or relationship with their significant other, scored higher on life satisfaction scale, reported a stronger sense of life purpose were found to demonstrate a higher level of psychological well-being.

Table 3. Unstandardized and standardized regression coefficients for effects of sociodemographic and background variables on psychological well-being

\begin{tabular}{|c|c|c|}
\hline & $\mathrm{b}$ & $\beta$ \\
\hline 1. Sex & 2.567 & $.240 * * *$ \\
\hline 2. Employment status & .070 & .007 \\
\hline 3. Socio-economic status & .072 & .012 \\
\hline 4. Religion & -.057 & -.035 \\
\hline 5. Physical health & .243 & .046 \\
\hline 6. Physical appearance & .690 & $.143 * *$ \\
\hline 7. Self-image & .576 & $.113 *$ \\
\hline 8. Life satisfaction & .340 & $.234 * * *$ \\
\hline 9. Purpose in life & .079 & $.094 *$ \\
\hline 10. Relationship with significant other & .394 & $.085 *$ \\
\hline 11. Relationship with family & -.060 & -.021 \\
\hline 12. Relationship with friends & -.089 & -.014 \\
\hline 13. Academic performance & .299 & .049 \\
\hline (Constant) & \multicolumn{2}{|c|}{1.974} \\
\hline $\mathrm{F}$ & \multicolumn{2}{|c|}{$16.038 * * *$} \\
\hline $\mathrm{R}^{2}$ & \multicolumn{2}{|c|}{.299} \\
\hline Adjusted $\mathrm{R}^{2}$ & \multicolumn{2}{|c|}{.281} \\
\hline $\mathrm{N}$ & \multicolumn{2}{|c|}{501} \\
\hline
\end{tabular}

$* p<.05 ; * * p<.01 ; * * * p<.001$ 


\section{Discussion and Conclusions}

The primary goal of the present investigation was to better understand the academic success and psychological health among university students in a western Canadian city. This inquiry reveals that a number of socio-demographic and background variables significantly contributed to the explanation of these two outcome variables.

Concerning academic performance, age was found to be positively associated with a higher GPA. This finding is probably related to the maturity level of the students (Hoskins, 1997). As well, senior undergraduate students might have adopted better approaches to learning as they would be more likely to have enrolled in courses that were directly related to their areas of specialization.

This study also provides support for the positive link between academic performance and educational aspirations (Chow, 2003; Kaufman \& Creamer, 1991). Consistent with previous studies (McFadden \& Dart, 1992; Paden \& Stell, 1997), students who put more time into studying performed better academically. In fact, there is empirical evidence that study time significantly interacts with ability to influence academic performance (Nonis \& Hudson, 2006). Additionally, as regular lecture attendance is indicative of students' commitment and motivation to their studies, this study corroborates findings from earlier research that class attendance and GPA are positively related (Billington, 2008; Fjortoft, 2005; Halpern, 2007; Lai \& Chan, 2000; Ledman \& Kammuche, 2002; Silvestri, 2003).

Father's educational attainment, as a measure of human capital that constitutes the potential for a cognitive environment conducive to learning, emerged as another variable predictive of students' GPA. This result may reflect the significance the fathers place on educational achievement and their specific encouragement of scholarly pursuits, confirming the enduring influence of parents' education on their offspring's educational attainment (Buchmann \& DiPrete, 2006; Mullen, Goyette, \& Soares, 2003; Nakhaie \& Curtis, 1998).

The present analysis also underscores the importance of students' physical health on academic performance. This finding is in line with prior research which has highlighted the 
vitality of various health-related variables on students' GPA, including exercise, sleep habits, and nutritional habits (George, Dixon, Stansal, Gelb, \& Pheri, 2008; Miller, Danner, \& Staten, 2008; Trockel et al., 2000). Without doubt, health issues that affect students' ability to attend lectures, complete assignments, write papers, or take examinations may have a negative impact on their ability to succeed academically.

Finally, as the adverse effects of stress (Haines et al., 1996; Hilary \& Brent, 1994) on students' academic performance have been well-documented, it is not difficult to understand that students who exhibited better psychological well-being were found to perform better academically (McKenzie \& Schweitzer, 2001; Vaez \& Laflamme, 2008).

Concerning psychological well-being, as previous studies have shown that female university students were more likely to experience a greater number of stressors (Misra, McKean, West, \& Russo, 2000) and to report a higher level of perceived stressfulness (Day \& Livingstone, 2003), it is unsurprising that male students were found to report a higher level of psychological well-being in the present analysis.

In addition, relationships, as an indirect measure of support, appear to be of particular importance to these undergraduate students. Those who reported more positive relationships with their significant other exhibited higher levels of psychological well-being. Earlier studies have ascertained that support and well-being are positively linked and that support can buffer the effects of negative events and stress (Cotton, Dollard, \& De Jonge, 2002; Gencoz \& Ozlale, 2004; Nezlek \& Allen, 2006). As noted by Home (1997, 1998), there is empirical research suggesting that it is often the individual's perceived satisfaction, rather than the absolute number of instrumental and emotional supports available, that affect psychological outcomes. Furthermore, low quality of emotional support was shown to be related to poorer psychological functioning among female university students (Carney-Crompton \& Tan, 2002).

Satisfaction with physical appearance and self-image emerge as two other factors contributing to students' psychological well-being. These findings mirror the results from earlier research (Chow, 2002; Harter, 1999; Huebner \& Alderman, 1993; Lackovic-Grgin, Dekovic, Milosavljevic, Cvek-Soric, \& Opacic, 1996; Leung \& Leung, 1992; Neto, 2001; Wilson \& Peterson, 1988) which reveal that individuals who accept themselves in a positive manner and 
believe that a similar viewpoint is shared by others will develop a more favourable evaluation of their general well-being and overall life conditions.

As expected, a positive association was found between life satisfaction and psychological health (Pai, 1996; Yanez, 1995). Students who were more satisfied with their life circumstances were found to report a higher level of psychological well-being. Finally, life purpose was found to be another significant predictor. Students who had clear goals and a strong sense of direction in life exhibited better psychological well-being (Adams, Bezner, Drabbs, Zambaranom, \& Steinhardt, 2000; King, Richards, \& Stemmerich, 1998).

To conclude, post-secondary institutions play a critical role in training individuals to compete and succeed in a knowledge-driven, information global economy, and an increasingly diverse and complex society. The institutional environment should be challenging, supportive, and capable of nurturing optimal learning and performance in students. Equally important, these institutions should be committed to providing programs and activities that will enhance the quality of life for students. The results of this study contribute to the research literature on students' performance and well-being. In particular, the key factors affecting the academic performance and psychological well-being in a sample of Canadian undergraduate students have been identified. Through increased understanding of the major determinants of both outcome variables, academic advisors, educators, counsellors, and community health professionals will be better equipped to design intervention strategies which enhance students' quality of life and facilitate student learning. The present study has limitations that researchers need to consider when weighing the impact of the findings. As this survey was undertaken on a group of students at a mid-sized university in a western Canadian city, some of the findings may be unique to this institution and this particular sample of students. This study is also limited by the reliance on self-reported data. Caution should therefore be exercised in interpreting the findings. An agenda for further research should include an examination of variation across types of post-secondary institutions (e.g., community colleges, university colleges, and institutes of technology) and student populations in other geographical locations (e.g., large metropolitan areas vs. smaller cities). It would also be worthwhile to investigate the specific sources of academic and psychological stress and coping strategies among postsecondary students. 


\section{Acknowledgements}

This survey was conducted with the financial support of the Department of Sociology and Social Studies at the University of Regina. A considerable debt is owed to M. Nelson, T. Bigayan, T. Busch, B. Carbrera, J. Freistadt, S. Hanna, T. Holsten, S.M. Keys, K-A McLeod, D. Partridge, C. Paul, T. Pinay, S. Skelding, H. Sugimoto, J. Youck, and G. Young for their valuable research assistance, and to John Conway, Paul Gingrich, Yau-tsang Chan, Angel Chow, Christie Chow, Simon Kwan, Sutton Cheung, Stephen Tam, Shue-ho Chow, Chap Wong, and Thomson $\mathrm{Yu}$ for their unwavering support. Gratitude is expressed to the two anonymous reviewers for their helpful comments on an earlier draft of this manuscript.

\section{References}

Adams, T.B., Bezner, J.R., Drabbs, M.E., Zambaranom, R.J., \& Steinhardt, M.A. (2000). Conceptualization and measurement of the spiritual and psychological dimensions of wellness in a college population. Journal of American College Health, 48, 165-173.

Applegate, C., \& Daly, A. (2006). The impact of paid work on the academic performance of students: A case study from the University of Canberra. Australian Journal of Education, 50(2), 155-166.

Baker, S.R. (2004). Intrinsic, extrinsic, and amotivational orientations: Their role in university adjustment, stress, well-being, and subsequent academic performance. Current Psychology, 23(3), 189-202.

Bean, J.P., \& Bradley, R.K. (1986). Untangling the satisfaction-performance relationship for college students. Journal of Higher Education, 57(4), 393-412.

Bibby, R.W. (2001). Canada's teens: Today, yesterday and tomorrow. Toronto: Stoddart Publishing Co. Limited.

Billington, P.J. (2008). Impact of student attendance on course grades. Journal of American Academy of Business, Cambridge, 12(2), 256-262.

Buchmann, C., \& DiPrete, T. (2006). The growing female advantage in college completion: The role of family background and academic achievement. American Sociological Review, 71(4), 515-541. 
Carney-Crompton, S., \& Tan, J. (2002). Support systems, psychological functioning, and academic performance of non-traditional female students. Adult Education Quarterly, $52,140-154$.

Chambel, M.J., \& Curral, L. (2005). Stress in academic life: Work characteristics as predictors of student well-being and performance. Applied Psychology: An International Review, 54(1), 135-147.

Chang, E.C. (2006). Perfectionism and dimensions of psychological well-being in a college student sample: A test of a stress-mediation model. Journal of Social and Clinical Psychology, 25(9), 1001-1022.

Chow, H.P.H. (2002). Life satisfaction, educational experience, and academic performance: A survey of university students in Regina. Regina, Saskatchewan: University of Regina.

Chow, H.P.H. (2003). Exploring the predictors of educational experience and academic performance among university students in Regina. The Alberta Journal of Educational Research, $X L I X(1), 101-105$.

Chow, H.P.H. (2008). Social attitudes and personal well-being: A survey of university students in Regina. Regina, Saskatchewan: University of Regina.

Clifton, R.A. (1997). The effects of social psychological variables and gender on the grade point averages and educational expectations of university students: A case study. The Canadian Journal of Higher Education, 27(2), 67-90.

Clifton, R.A., Perry, R.P., Roberts, L.W., \& Peter, T. (2008). Gender, psychosocial dispositions, and the academic achievement of college students. Research in Higher Education, 49, 684-703.

Cook, R., Bewick, B.M., Barkham, M., Bradley, M., \& Audin, K. (2006). Measuring, monitoring and managing the psychological well-being of first year university students. British Journal of Guidance and Counselling, 34(4), 505-517.

Cotton, S.J., Dollard, M.F., \& De Jonge, J. (2002). Stress and student job design: Satisfaction, well-being, and performance in university students. International Journal of Stress Management, 9, 147-162.

Cutrona, C.E., Cole, V., Colangelo, N., Assouline, S.G., \& Russell, D.W. (1994). Perceived parental support and academic achievement: An attachment theory perspective. Journal of Personality and Social Psychology, 66(2), 369-378. 
Day, A.L., \& Livingstone, H.A. (2003). Gender differences in perceptions of stressors and utilization of social support among university students. Canadian Journal of Behavioural Science, 35(2), 73-83.

DeBerard, M.S., Spielmans, G.I., \& Julka, D.L. (2004). Predictors of academic achievement and retention among college freshmen: A longitudinal study. College Student Journal, $38(1), 66-80$.

Diseth, A. (2002). The relationship between intelligence, approaches to learning and academic achievement. Scandinavian Journal of Educational Research, 46(2), 219-230.

Duff, A. (2004). Understanding academic performance and progression of first-year accounting and business economics undergraduates: The role of approaches to learning and prior academic achievement. Accounting Education, 13(4), 409-430.

Dyson-Washington, F. (2006). The relationship between optimism and work-family enrichment and their influence on psychological well-being. Ph.D. thesis, Drexel University.

Edwards, K.J., Hershberger, P.J., Russell, R.K., \& Markert, R.J. (2001). Stress, negative social exchange, and health symptoms in university students. Journal of American College Health, 50(2), 75-79.

Elliot, A.J., Sheldon, K.M., \& Church, M.A. (1997). Avoidance personal goals and subjective well-being. Personality and Social Psychology Bulletin, 23(9), 915-927.

Fjortoft, N. (2005). Students' motivations for class attendance. American Journal of Pharmaceutical Education, 69, 107-112.

Frey, L.L., Beesley, D., \& Miller, M.R. (2006). Relational health, attachment, and psychological distress in college men and women. Psychology of Women Quarterly, 30(3), 303311.

Gencoz, T., \& Ozlale, Y. (2004). Direct and indirect effects of social support on psychological well-being. Social Behavior and Personality, 32(5), 449-458.

George, D., Dixon, S., Stansal, E., Gelb, S.L., \& Pheri, T. (2008). Time diary and questionnaire assessment of factors associated with academic and personal success among university undergraduates. Journal of American College Health, 56(6), 706-715.

Graunke, S.S., \& Woosley, S.A. (2005). An exploration of the factors that affect the academic success of college sophomores. College Student Journal, 39(2), 367-376.

Haines, M.E., Norris, M.P., \& Kashy, D.A. (1996). The effects of depressed mood on academic performance in college students. Journal of College Student Development, $37(5), 519-525$. 
Hall, C., Smith, K., \& Chia, R. (2008). Cognitive and personality factors in relation to timely completion of a college degree. College Student Journal, 42(4), 1087-1098.

Halpern, N. (2007). The impact of attendance and student characteristics on academic achievement: Findings from an undergraduate business management module. Journal of Further and Higher Education, 31(4), 335-349.

Hansen, M.N., \& Mastekaasa, A. (2006). Social origins and academic performance at university. European Sociological Review, 22(3), 277-291.

Harter, S. (1999). The construction of self: A developmental perspective. New York: Guilford.

Heris, P., \& Revilla, L.A. (1994). Acculturation, generational status, and family environment of Philipino Americans: A study in cultural adaptation. Family Therapy, 21(2), 129138.

Hilary, G., \& Brent, M. (1994). Emotional, social, and academic adjustment of college students: A longitudinal study of retention. Journal of Counseling and Development, 72, 281-285.

Home, A. (1997). Learning the hard way: Role strain, stress, role demands, and support in multiple-role women students. Journal of Social Work Education, 33, 335-347.

Home, A. (1998). Predicting role conflict, overload and contagion in adult women university students with families and jobs. Adult Education Quarterly, 48, 85-98.

Hoskins, S.L. (1997). Degree performance as a function of age, gender, prior qualifications and discipline studied. Assessment and Evaluation in Higher Education, 22(3), 317328.

Huebner, E.S., \& Alderman, G.L. (1993). Convergent and discriminant validation of a children's life satisfaction: Its relationship to self- and teacher-reported psychological problems and functioning. Social Indicators Research, 30, 71-83.

Hunt, A., Lincoln, I., \& Walker, A. (2004). Term-time employment and academic attainment: Evidence from a large-scale survey of undergraduate students at Northumbria University. Journal of Further and Higher Education, 28(1), 3-18.

Jackson, T., Weiss, K.E., Lundquist, J.J., \& Hooper, D. (2003). The impact of hope, procrastination, and social activity on academic performance of Midwestern college students. Education, 124(2), 310-320.

Kaufman, M.A., \& Creamer, D.G. (1991). Influences of student goals for college on freshman-year quality of effort and growth. Journal of College Student Development, 32, 197-206. 
Kazarian, S.S. (2005). Family functioning, cultural orientation, and psychological well-being among university students in Lebanon. The Journal of Social Psychology, 145(2), 141152.

Keller, D., Crouse, J., \& Trusheim, D. (1993). Relationships among gender differences in freshman course grades and course characteristics. Journal of Educational Psychology, 85(4), 702-709.

King, L.A., Richards, J.H., \& Stemmerich, E. (1998). Daily goals, life goals, and worse fears: Means, ends, and subjective well-being. Journal of Personality, 66(5), 713-744.

Lackovic-Grgin, K., Dekovic, M., Milosavljevic, B., Cvek-Soric, I., \& Opacic, G. (1996). Social support and self-esteem in unemployed university graduates. Adolescence, 31, 701-708.

Lai, P., \& Chan, K. (2000). Should class attendance be mandatory? Atlantic Economic Journal, 28(3), 377.

Ledman, R.E., \& Kammuche, F. (2002). Improving student attendance: Does it improve student learning? Academic Exchange Quarterly, 6, 76-80.

Lee, R.L.T., \& Yuen-Loke, A.J.T. (2005). Health-promoting behaviors and psychosocial well-being of university students in Hong Kong. Public Health Nursing, 22(3), 209220.

Leung, J.P., \& Leung, K. (1992). Life satisfaction, self-concept, and relationship with parents in adolescence. Journal of Youth and Adolescence, 21, 653-666.

Love, K.M., \& Murdock, T.B. (2004). Attachment to parents and psychological well-being: An examination of young adult college students in intact families and stepfamilies. Journal of Family Psychology, 18(4), 600-608.

Maltby, J., \& Day, L. (2001). The relationship between exercise motives and psychological well-being. The Journal of Psychology, 135(6), 651-660.

Markland, D., \& Ingledew, D.K. (1997). The measurement of exercise motives: Factorial validity and invariance across gender of a revised exercise motivations inventory. British Journal of Health Psychology, 2, 361-376.

Mattison, V. (2006). The relationship between health behaviors and academic performance among undergraduate college students attending a four year university in the northeast. M.P.H. thesis, Southern Connecticut State University.

Mattson, C.E. (2007). Beyond admission: Understanding pre-college variables and the success of at-risk students. Journal of College Admission, 196, 8-13. 
Mau, W., \& Lynn, R. (2001). Gender differences on the scholastic aptitude test, the American college test and college grades. Educational Psychology, 21(2), 133-137.

McCabe, R.E., Blankstein, K.R., \& Mills, J.S. (1999). Interpersonal sensitivity and social problem-solving: Relations with academic and social self-esteem, depressive symptoms, and academic performance. Cognitive Therapy and Research, 23(6), 587-604.

McFadden, K., \& Dart, J. (1992). Time management skills of undergraduate business students. Journal of Education for Business, 68, 85-88.

McKenzie, K., \& Schweitzer, R. (2001). Who succeeded at university? Factors predicting academic performance in first year Australian university students. Higher Education Research and Development, 20(1), 21-33.

Miller, K., Danner, F., \& Taten, R. (2008). Relationship of work hours with selected health behaviors and academic progress among a college student cohort. Journal of American College Health, 56(6), 675-679.

Miller, L.S. (2001). Psychological well-being among university students: Problem solving, career decision-making attitudes, and program commitment. Ph.D. thesis, University of Ottawa.

Misra, R., McKean, M., West, S., \& Russo, T. (2001). Academic stress of college students: Comparison of student and faculty perceptions. College Student Journal, 34, 236-245.

Monk, E.M., \& Mahmood, Z. (1999). Student mental health: A pilot study. Counselling Psychology Quarterly, 12(2), 199-210.

Morris, E.A., Brooks, P.R., \& May, J.L. (2003). The relationship between achievement goal orientation and coping style: Traditional vs nontraditional college students. College Student Journal, 37(1), 3-9.

Morris, J.K. (1997). Latino college students: The impact of stress, acculturation, and social support on psychological well-being and distress. Ph.D. thesis, California School of Professional Psychology.

Mullen, A.L., Goyette, K.A., \& Soares, J.A. (2003). Who goes to graduate school? Social and academic correlates of educational continuation after college. Sociology of Education, 76, 143-0169.

Musgrave-Marquart, D., Bromley, S.P., \& Dalley, M.B. (1997). Personality, academic, attribution, and substance use as predictors of academic achievement in college students. Journal of Social Behavior and Personality, 12(2), 501-511. 
Nakhaie, M.R., \& Curtis, J. (1998). Effects of class positions of parents on educational attainment of daughters and sons. The Canadian Review of Sociology and Anthropology, $35(4), 483-515$.

Neto, F. (2001). Satisfaction with life among adolescents from immigrant families in Portugal. Journal of Youth and Adolescence, 30, 53-67.

Nezlek, J.B., \& Allen, M.R. (2006). Social support as a moderator of day-to-day relationships between daily negative events and daily psychological well-being. European Journal of Personality, 20, 53-68.

Nguyen, N.T., Allen, L.C., \& Fraccastoro, A.K. (2005). Personality predicts academic performance: Exploring the moderating role of gender. Journal of Higher Education Policy and Management, 27(1), 105-116.

Nonis, S.A., \& Hudson, G.I. (2006). Academic performance of college students: Influence of time spent studying and working. Journal of Education for Business, 81(3), 151-159.

Olani, A. (2009). Predicting first year university students' academic success. Electronic Journal of Research in Educational Psychology, 7(3), 1053-1072.

Orpen, C. (1996). The interactive effects of social support and test anxiety on student academic performance. Education, 116(3), 464-465.

Pacific Issues Partners. (2006). Canadian attitudes on post-secondary education: A report for the Canadian Council on Learning. Ottawa: Canadian Council on Learning.

Paden, N., \& Stell, R. (1997). Reducing procrastination through assignment and course design. Marketing Education Review, 7, 17-25.

Pai, H.C. (1996). Reentry difficulty, life satisfaction, and psychological well-being of Taiwanese students who have returned from the United States. Ph.D. thesis, University of Florida.

Pike, G.R. (1991). The effects of background, coursework and involvement on students' grades and satisfaction. Research in Higher Education, 32(1), 15-40.

Pike, G. R., \& Saupe, J. L. (2002). Does high school matter? An analysis of three methods of predicting first year grades. Research in Higher Education, 43, 187-207.

Ridgell, S.D., \& Lounsbury, J.W. (2004). Predicting academic success: General intelligence, "big five" personality traits, and work drive. College Student Journal, 38(4), 607-618.

Roberts, R., Golding, J., Towell, T., \& Weinreb, I. (1999). The effects of economic circumstances on British students' mental and physical health. Journal of American College Health, 48, 103-109. 
Rodriguez, N., Mira, C.B., Myers, H.F., Morris, J.K., \& Cardoza, D. (2004). Family or friends: Who plays a greater supportive role for Latino college students? Cultural Diversity and Ethnic Minority Psychology, 9(3), 236-250.

Roebken, H. (2007). The influence of goal orientation on student satisfaction, academic engagement and achievement. Electronic Journal of Research in Educational Psychology, 5(3), 679-704.

Ross, S., Cleland, J., \& MacLeod, M.J. (2006). Stress, debt, and undergraduate medical student performance. Medical Education, 40, 584-589.

Silvestri, L. (2003). The effect of attendance on undergraduate methods course grades. Education, 123(3), 483-487.

Solberg, V.S., \& Villarreal, P. (1997). Examination of self-efficacy, social support, and stress and predictors of psychological and physical distress among Hispanic college students. Hispanic Journal of Behavioral Sciences, 19, 182-201.

Spitzer, T.M. (2000). Predictors of college success: A comparison of traditional and nontraditional age students. NASPA Journal, 38(1), 82-98.

Statistics Canada (2003a). Census of population: Earnings, levels of schooling, field of study and school attendance. The Daily, March 11.

Statistics Canada (2003b). Education in Canada: Raising the standard. Ottawa: Ministry of Industry.

Statistics Canada (2007). University tuition fees, 2007/2008. The Daily, October 18.

Statistics Canada (2009a). Education indicators in Canada: An international perspective. The Daily, September 8.

Statistics Canada (2009b). University tuition fees, 2009/2010. The Daily, October 20.

Statistics Canada (2010). University enrolment, 2008/2009. The Daily, July 14.

Steinberg, L.C. (2006). The graying freshman: Examining achievement motivation goals and academic performance in traditional and non-traditional undergraduate students. M.S. (Ed.) thesis, University of Kansas.

Stewart-Brown, S., Evans, J., Patterson, J., Peterson, S., Doll, H., Balding, J., \& Regis, D. (2000). The health of students in institutes of higher education: An important and neglected public health problem? Journal of Public Health Medicine, 22, 492-499.

Terenzini, P.T., Pascarella, E.T., \& Lorang, W.G. (1982). An assessment of the academic and social influences on freshman year educational outcomes. Review of Higher Education, 5, 86-109. 
Tomiki, K. (2000). Achievement motivation and psychological well-being in Asian American college students: The contribution of intergenerational congruence of academic expectations. Ph.D. thesis, University of California, Berkeley.

Tong, Y., \& Song, S. (2004). A study on general self-efficacy and subjective well-being of low SES college students in a Chinese university. College Student Journal, 38(4), 637-642.

Trockel, M.T., Barnes, M.D., \& Egget, D.L. (2000). Health-related variables and academic performance among first-year college students: Implications for sleep and other behaviors. Journal of American College Health, 49, 125-131.

Tross, S.A., Harper, J.P., Osher, L.W., \& Kneidinger, L.M. (2000). Not the usual cast of characteristics: Using personality to predict college performance and retention. Journal of College Student Development, 4(3), 323-334.

Vaez, M., \& Laflamme, L. (2008). Experienced stress, psychological symptoms, self-rated health and academic achievement: A longitudinal study of Swedish university students. Social Behavior and Personality, 36(2), 183-196.

Walker, K.L., \& Satterwhite, T. (2002). Academic performance among African American and Caucasian college students: Is the family still important? College Student Journal, 36, 113-128.

Wilding, J., \& Andrews, B. (2006). Life goals, approaches to study and performance in an undergraduate cohort. British Journal of Educational Psychology, 76, 171-182.

Wilson, S.M., \& Peterson, G.W. (1988). Life satisfaction among young adults from rural families. Family Relations, 37, 84-91.

Wolniak, G.C., \& Engberg, M.K. (2010). Academic achievement in the first year of college: Evidence of the pervasive effects of the high school context. Research in Higher Education, 51, 451-467.

Yanez, A.P. (2004). Existential predictors of psychological well-being. M.A. thesis, University of Nevada, Las Vegas.

Zwick, R., \& Sklar, J.C. (2005). Predicting college grades and degree completion using high school grades and SAT scores: The role of student ethnicity and first language. American Educational Research Journal, 42(3), 439-464.

\section{Notes}

(1) Drawing on nationwide surveys of young people in Canada, it has been projected that more than one in six of the teenagers today expect to graduate from university and another one in ten anticipate at least enrolling in a university program (Bibby, 2001). 
(2) Canadian full-time undergraduate students paid an average of \$ 4,917 in tuition fees for the 2009-2010 academic year, up from $\$ 4,747$ the year before. During the 1990s, the undergraduate tuition fees increased at an annual average rate of more than $9.6 \%$. Since 2000, increases have slowed to an average of $3.8 \%$ (Statistics Canada, 2009b, 2007).

(3) Of the 501 survey respondents, 6 did not respond to the sex/gender question.

(4) A total of eleven predictor variables were included in the multiple OLS regression model for academic performance. Sex $(1=$ male; $0=$ female $)$ employment status $(1=$ employed; $0=$ not employed), and religion $(1=$ Protestant and Catholic; $0=$ other $)$ were measured as dichotomous variables. Age $(M=21.42, S D=4.91)$ was a continuous variable. Employment status was a categorical variable $(1=$ employed; $0=$ not employed $)$. Physical health $(M=3.83, S D=$ .92) was measured on a five-point scale $(1=$ very dissatisfied to $5=$ very satisfied $)$. Psychological well-being was a composite score $(M=19.46, S D=4.92)$ based on frequency of feeling $\operatorname{sad}(M=2.91, S D=.954)$, lonely $(M=2.71, S D=1.125)$, stressed $(M=3.95, S D=.951)$, like crying $(M=2.70, S D=1.215)$, depressed $(M=2.41, S D=1.16)$, and hopeless $(M=1.84, S D$ $=1.061)$ in the past 30 days on a five-point scale $(1=$ never; $2=$ very infrequently; $3=$ infrequently; 4 = frequently; 5 = very frequently). This scale was found to be internally consistent, with a Cronbach's alpha reliability coefficient of .85 . The academic program that respondents intended to complete $(1=$ no degree or diploma or certificate; $2=$ university diploma or certificate; 3 = bachelor's degree; 4 = master's degree; $5=$ doctoral degree) was used as a measure of educational aspirations $(\mathrm{M}=3.47, \mathrm{SD}=.82)$. Class attendance was based on respondents' degree of agreement with the statement "I attend classes on a regular basis, i.e., at least $80 \%$ or more" on a five-point scale $(M=4.49, S D=.77)$. Hours spent on studying $(M=14.75, S D$ $=11.59)$ was a continuous variable. Father's education was a categorical variable $(1=$ no formal education; 2 = primary school; $3=$ secondary school; $4=$ community college; $5=$ university; 6 = graduate school). Socio-economic status $(M=7.11, S D=2.06)$ was an additive scale (Cronbach's alpha reliability coefficient $=.55$.) based on respondents' self-assessed socio-economic status $(1=$ low to $5=$ high $)$ and family's total yearly income $(1=\$ 20,000 ; 2=$ $\$ 20,001$ to 40,$000 ; 3=\$ 40,001$ to 60,$000 ; 4=\$ 60,001$ to 80,$000 ; 5=\$ 80,001$ to $\$ 100,000$ or under to $6=\$ 100,001$ or more).

(5) A total of thirteen predictor variables were included in the multiple OLS regression model for psychological well-being. Sex $(1=$ male; $0=$ female $)$ and employment status $(1=$ employed; 0 $=$ not employed $)$ were dichotomous variables. Socio-economic status $(M=3.41, S D=.8)$ was a continuous variable based on a five-point scale ranging from 1 (low) to 5 (high). Time spent on religious activities $(\mathrm{M}=1.18, \mathrm{SD}=2.986)$ was based on the number of hours per week. Satisfaction with physical health $(M=3.83, S D=.92)$, physical appearance $(M=3.4, S D=$ $1.01)$, and self-image $(M=3.65, S D=.95)$ were measured on a five-point scale ranging from 1 
(very dissatisfied) to 5 (very satisfied). Life satisfaction was a five-item scale based on respondents' degree of agreement $(1=$ strongly disagree to $5=$ strongly agree $)$ with the following five items: (1) In most ways my life is close to my ideal $(M=3.62, S D=.826)$; (2) The conditions of my life are excellent $(M=3.73, S D=.876)$; (3) I am satisfied with my life $(M=3.87$, $S D=.811)$; (4) So far I have gotten the important things I want in life $(M=3.53, S D=.995)$; and (5) If I could live my life over, I would change almost nothing ( $M=3.28, S D=1.125)$. This additive scale $(M=18.04, S D=3.38)$ was found to be internally consistent, with a Cronbach's alpha reliability coefficient of .772. Life purpose was a ten-item scale $(M=40.87, S D=$ 5.84) based on respondents' degree of agreement with the following statements $(1=$ strongly disagree to $5=$ strongly agree): (1) My life has clear goals and aims $(M=3.84, S D=.854)$; (2) I feel my life has a sense of direction $(M=3.96, S D=.764)$; (3) I feel my life has a sense of meaning $(M=4.04, S D=.766)$; (4) My personal existence is full of purpose $(M=3.92, S D=$ $.811)$; (5) There are things I still want to achieve in my life $(M=4.65, S D=.57)$; (6) My personal existence is full of direction $(M=3.86, S D=.817)$; (7) I feel my life has a sense of purpose $(M=4.04, S D=.766)$; (8) My personal existence is full of meaning $(M=3.91, S D=$ $.821)$; (9) I feel my life is going nowhere $(M=1.69, S D=.834)$; and (10) There is no purpose in what I am doing $(M=1.63, S D=.847)$. The coding for the last two statements was reversed so that a higher composite score would reflect a stronger sense of life purpose. This scale was found to be internally consistent, with a Cronbach's alpha reliability coefficient of .909. Degree of satisfaction with relationships with significant other $(M=3.67, S D=1.06)$ and with friends $(M=4.12, S D=.75)$ was based on a five-point scale ranging from 1 (very dissatisfied) to 5 (very satisfied). Satisfaction with family was a two-item scale $(M=7.93, S D=1.7)$ based on degree of satisfaction with the relationships with parents and siblings, with a Cronbach's alpha reliability coefficient of .60. Finally, academic performance was based on self-reported overall grade point average $(M=3.92, S D=.81)$ on a five-point scale $(1=$ under $50 ; 2=50$ $59 ; 3=60-69 ; 4=70-79 ; 5=80-89 ; 6=90-100)$. 